University of Rhode Island

DigitalCommons@URI

The Rhode Island Current Conditions Index

Economics

6-2015

\title{
Rhode Island Current Conditions Index -- June 2015
}

Leonard Lardaro

University of Rhode Island, lardaro@uri.edu

Follow this and additional works at: https://digitalcommons.uri.edu/ricci

Part of the Econometrics Commons

Terms of Use

All rights reserved under copyright.

\section{Recommended Citation}

Lardaro, Leonard, "Rhode Island Current Conditions Index -- June 2015" (2015). The Rhode Island Current Conditions Index. Paper 129.

https://digitalcommons.uri.edu/ricci/129

This Article is brought to you for free and open access by the Economics at DigitalCommons@URI. It has been accepted for inclusion in The Rhode Island Current Conditions Index by an authorized administrator of DigitalCommons@URI.For more information, please contact digitalcommons-group@uri.edu. 


\title{
CURRENT CONDITIONS
}

\section{LEONARD LARDARO, URI}

\author{
Available Online: http:/ / www .Ilardaro.com/ current.htm \\ Blog: http:/ / rieconomy.blogspot.com \\ Twitter: @ladardo
}

VOL XXLT

NUMBER 7

JUN 2015
Rhode Island's economy showed more strength in June than we have become accustomed to. More importantly, this month's data provided further evidence that Rhode Island's rate of economic growth is continuing to move farther above its disappointing value of only 1.2 percent last year. The Current Conditions Index for June attained a respectable value of 75 , its highest yet this year, as nine of the $\mathrm{CCl}$ indicators improved relative to their values last June. Better yet, the $\mathrm{CCl}$ has now matched or exceeded its yearearlier value for the last four months!

Underlying this was yet another strong month for labor market data. As was true for May, virtually all of the key labor market numbers in June moved in the direction we want them to move and for the right reasons. This was especially true for our Unemployment Rate which was once again accompanied by an improving Labor Force (both on a monthly and yearly basis). For Rhode Island, as strange as this might sound, that's a big deal, since our state's Labor Force had until recently been declining for two consecutive years (on a year-over-year basis). Ironically, this meant that the dramatic declines in our state's Unemployment

\begin{tabular}{|l|r|r|}
\hline \multicolumn{3}{|c|}{ CCI Indicators - \% Change } \\
\hline Government Employment & -1.3 & \\
\hline US Consumer Sentiment & 16.6 & Y \\
\hline Single-Unit Permits & 16.5 & Y \\
\hline Retail Sales & 6.1 & Y \\
\hline Employment Services Jobs & 5.5 & Y \\
\hline Priv. Serv-Prod Employment & 2.0 & Y \\
\hline Total Manufacturing Hours & -1.8 & \\
\hline Manufacturing Wage & $-\mathbf{5 . 3}$ & \\
\hline Labor Force & 0.6 & Y \\
\hline Benefit Exhaustions & -22.8 & Y \\
\hline New Claims & -16.7 & Y \\
\hline Unemployment Rate (change) & $-\mathbf{1 . 8}$ & Y \\
\hline \multicolumn{2}{|c|}{ Y = Improved Value } & \\
\hline
\end{tabular}

Rate were largely spurious, since they were generally occurring in spite of improving employment, driven primarily by a Labor Force that continued to trend lower. While we have still only recovered about 70 percent of the jobs lost during the last recession, the pace at which these lost jobs are being recovered now appears to be accelerating

Rhode Island's June economic performance really was quite good. Nine indicators improved overall, which included four of the five leading indicators contained in the Current Conditions Index. New home construction, in terms of Single-Unit Permits, improved for the first time since the harsh winter weather ended, moving above 1,000 annual units (seasonally adjusted), its highest value since February of 2013. Even better, it finally exceeded its twelvemonth average. Total Manufacturing Hours, a measure of manufacturing sector strength, also declined in June $(-1.8 \%)$, its third consecutive decline, but it did have a very difficult comp to beat from last June $(+4.4 \%)$. All of the remaining leading indicators contained within the $\mathrm{CCl}$ improved in June. US Consumer Sentiment rose at a double-digit rate $(+16.6 \%)$ for the ninth consecutive month. Employment Service Jobs, which includes temporary employment and is a prerequisite to employment growth, improved at its most rapid rate since last August $(+5.5 \%)$. This was its fourth consecutive improvement, and it occurred in spite of a very difficult comp from last June. Finally, New Claims, a leading labor market indicator that reflects layoffs, fell by 16.7 percent in June, sustaining its well-defined downtrend.

Retail Sales turned in another strong performance in June $(+6.1 \%)$, following a double-digit rise in April and a 9.7 percent gain in May. This indicator has now improved for fourteen consecutive months. Private Service-Producing Employment increased by 2 percent in June, its most rapid growth rate since last August. Its rate of improvement has been accelerating for the past three months. Government Employment again failed to improve, declining by $\mathbf{1 . 3}$ percent for June, its worst performance in over a year. Benefit Exhaustions, which reflects longer-term unemployment, fell by 22.8 percent relative to last year. For those into fiction, Rhode Island's Manufacturing Wage declined for the sixteenth consecutive time in June $(-5.3 \%)$. Rhode Island's Labor Force sustained the end of its two-year string of year-overyear declines, rising by a hefty (for us) 0.6 percent in June. And, for only the second time in a very long time, Rhode Island's Unemployment Rate declined, this month to 5.9 percent (from an upwardly revised 6 percent in May), accompanied by large jumps in both resident employment $(+13,500$ or $2.6 \%$ yearover-year) and payroll employment $(5,700$ or $1.2 \%)$, along with a substantial decline in the number of unemployed $(9,900$ or $23.1 \%)$. Let's hope our state's Labor Force has now begun to increase on a sustained basis.
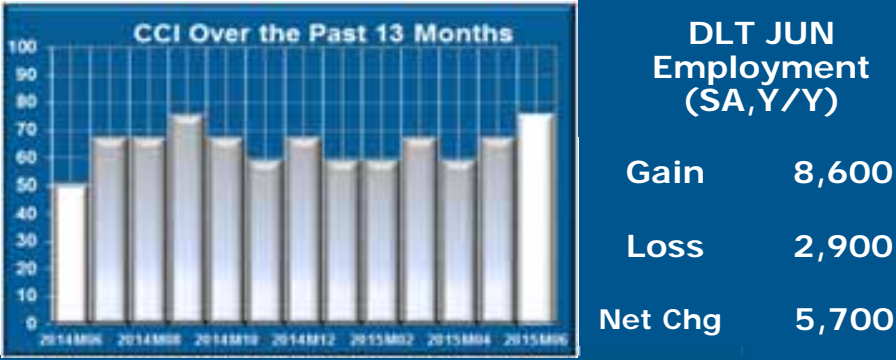

\section{THE BOTTOM LINE}

Rhode Island's economy appears to be transitioning to a more rapid rate of economic growth based not only on two solid months of labor market data, but the fact that the $\mathrm{CCl}$ has now matched or exceeded its year-earlier value for the most recent four months. Most importantly, this is occurring in spite of the fact that our state literally did nothing for several years. What we are witnessing now are the combined forces of our state's economy continuing to heal and the benefits we are deriving from national and neighboring state momentum. The good news is that the recently enacted legislation should prolong this once its effects begin to be felt later this year.

\begin{tabular}{|c|c|c|c|c|c|c|c|c|c|c|c|c|c|}
\hline & & Jan & Feb & Mar & Apr & May & J un & Jul & Aug & Sep & Oct & Nov & Dec \\
\hline & 2014 & 67 & $67 \uparrow$ & 58 & 58 & 58 & 50 & $67 \downarrow$ & $67 \downarrow$ & 75 & $67 \uparrow$ & 58 & $67 \downarrow$ \\
\hline & 2015 & 58 & 58 & 67 & 58 & 67 & 75 & & & & & & \\
\hline
\end{tabular}

